\section{A emergência epistemológica das Ciências da Comunicação no Brasil na obra 'Pensamento Comunicacional Brasileiro’}

DOI: 10.1590/1809-58442016114

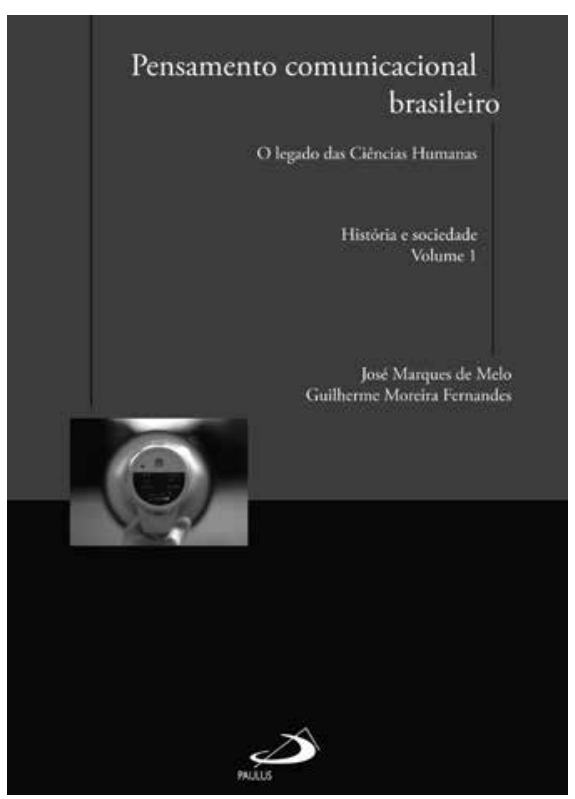

\author{
Élmano Ricarte de Azevêdo Souza \\ (Universidade Católica Portuguesa, Faculdade de \\ Ciências Humanas, Doutorado em Comunicação Social. \\ Lisboa, Portugal)
}

MELO, José Marques de; FERNANDES, Guilherme M. (Orgs.). Pensamento comunicacional brasileiro: o legado das Ciências Humanas - história e sociedade. v.1. São Paulo: Paulus, 2014. 672 p.

A Pesquisa em Comunicação no Brasil completa 52 anos desde a criação do Instituto de Ciências da Informação - ICINFORM (Pernambuco), pelo professor Luiz Beltrão em 1963 e, nos anos seguintes, da Escola de Comunicações Culturais (1966), pela Universidade de São Paulo - USP, e a instalação do Centro de Pesquisas em Comunicação Social (1967), pela Faculdade de Jornalismo Cásper Líbero (associada à Pontifícia Universidade Católica de São Paulo, na época). Tais fundações sinalizam uma tentativa de romper a marginalidade frente ao conhecimento produzido e difundido pelos países desenvolvidos no campo comunicacional. Um nome destacou-se nesse cenário: José Marques de Melo, primeiro doutor em Jornalismo pela USP (1973), com a tese Fatores socioculturais que retardaram a implantação da imprensa no Brasil. Suas frentes de ação passam pela criação de redes de investigadores e a produção bibliográfica. A mais recente foi lançada em parceria com o professor Guilherme Moreira Fernandes. Pensamento Comunicacional Brasileiro tem três volumes: História e Sociedade; Cultura; e Poder e Mídia e Consumo. A divisão facilita a leitura e a compreensão do surgimento e desdobramentos das investigações nas décadas seguintes. 
Cada volume é composto por duas partes e 12 textos base, os quais são comentados em duas nuances: uma bibliográfica destaca o percurso do autor e a contribuição do texto e outra contextualiza metodologicamente e atualiza a ideia. As partes centrais contêm três textos explicativos, um introdutório apresenta o bloco de seis textos base e os comentários e outros dois no fim: um visa uma costura teórica dos textos e o seguinte encerra com uma “reflexão pedagógica”.

O primeiro volume centra-se em valores morais nos processos de Comunicação. Os textos na primeira parte apontam a gênese e evolução da Comunicação humana e, na segunda, contribuem sobre esse processo no nível social básico. O volume seguinte aborda as características e elementos do campo. A primeira parte toma o ato de comunicar no fenômeno cultural e a segunda observa tal ação em sistemas de poder. O último volume promove um debate sobre a prática da Comunicação e sua inserção nas Ciências Humanas e Sociais. Apresentam-se os fluxos comportamentais (consumo, participação e opinião pública) em um primeiro momento e, no segundo, aborda a Comunicação nas Ciências Sociais Aplicadas.

Os autores apresentados nos volumes não são classificados como pesquisadores de Comunicação, mas têm contribuições diretas ou indiretas à formação da investigação brasileira nesse campo. O singular desta obra é que as exegeses atualizam e direcionam a ideia central de cada texto ao tema do pensamento comunicacional, resgatando o estado da arte desse pensar e oferecendo uma reflexão dialógica sobre a gênese e desenvolvimento de outras pesquisas. Ressalta-se que a maioria dos autores dos textos base é do Nordeste brasileiro, havendo apenas três mulheres. Marques de Melo introduz essa característica geral como um retrato da época e fazer diferente seria um “artificialismo inadmissível”. A solução está nos exegetas, cuja maioria é feminina da região Sudeste, contemplando instituições de ensino superior de todas regiões do país, com jovens e experientes investigadores em diversas áreas.

Sobre o primeiro volume, Lévi-Strauss observa comunidades primitivas e o matrimônio com membros externos e suas implicações na vida social de cada agrupamento a partir de um diálogo entre clãs distintos. Luís da Câmara Cascudo analisa a vizinhança no contexto urbano, no qual agentes comunicadores valorizam mais os contatos próximos, revelando aspectos de Comunicação social nos laços interpessoais. Nessa perspectiva de meios sociais locais, Jarbas Maciel estrutura os mecanismos de aprendizagem a partir das relações cognitivas e Florestan Fernandes as relações lúdicas do folclore da cidade de São Paulo. Barbosa Lima Sobrinho discute questões de linguística na formação da unidade territorial nacional brasileira no uso da Língua Portuguesa e seu teor político e econômico como estratégia da coroa lusitana no século 18, mantendo o monopólio nos portos. Ao fim dessa seção, Virgílio Noya Pinto explica sobre as rodovias da informação com base no significado político, cultural e econômico das 
estradas persas. Na seção seguinte, Emilio Willems decorre sobre ações de cooperação de comunidades em atos de "mutirão" e associativismo, revelando a existência de uma forte Comunicação a nível local. Alceu Maynard Araújo analisa a Comunicação comunitária em uma cidade do interior alagoano. Paulo Freire, na interpretação dos exegetas, apresenta uma “Comunicação libertadora”, sendo a educação discutida como forma de emancipação do indivíduo. Manuel Diégues Júnior relata a Comunicação intercultural no trânsito de pessoas no contexto da imigração e suas implicações nos processos de industrialização e urbanização no Brasil. Antonio Candido observa a Comunicação literária ao estudar o sentido psicossocial da vingança pelos folhetins franceses. E Fernando de Azevedo registra a Comunicação cidadã e a formação da opinião pública com a educação no cenário urbano.

A obra oferece textos de autores de áreas transversais à Comunicação com origem brasileira e temas nacionais. Com as exegeses, há uma costura no campo comunicacional, traçando um apanhado histórico e intelectual do conhecimento produzido no país. Há um caráter metalinguístico na obra, pois a Ciência da Comunicação no Brasil pensa sobre si, ajudando seus pares a se reconhecerem ao expor sua gênese e o conhecimento até agora produzido, colaborando na formação de uma identidade epistemológica.

Constata-se uma contribuição à emergência de um paradigma da Comunicação de forma inter \& transdisciplinar: histórico, biológico, pedagógico, antropológico, etimológico, sociológico, e psicológico (MARQUES DE MELO, 1971) ${ }^{1}$. Verifica-se, a partir dos textos escolhidos, uma interação com outras ciências, produzindo um saber rico epistemologicamente e contextualizado com a realidade social, cuja diferença é basilar quando comparado ao paradigma dito hegemônico, o qual se vê como única forma de saber, excluindo os demais e não provendo diálogo, criando abismos epistemológicos como afirma Santos (2004). É preciso construir uma ecologia de saberes (SANTOS, 2002), promovendo também debates com investigadores distintos e em línguas ditas hegemônicas, em um diálogo cujo caminho traçado e os resultados de ambas as partes sejam valorizados de forma horizontal.

\section{Élmano Ricarte de Azevêdo Souza (autor da resenha)}

Doutorando em Ciências da Comunicação, Universidade Católica Portuguesa - UCP (Bolsista da CAPES). Mestrado na linha de Pesquisa de Produção de Sentido do Programa de Pós-graduação de Estudos da Mídia da UFRN. Graduado em Jornalismo e em Radialismo pela Universidade Federal

MARQUES DE MELO, José. Comunicação social: teoria e pesquisa. 2.ed. Petrópolis: Editora Vozes, 1971. 
do Rio Grande do Norte - UFRN (Brasil), com graduação sanduíche na UCP. Investigador Júnior do Centro de Estudos de Comunicação e Cultura - CECC/UCP. Integrante do OBES - Observatório BOA-VENTURA de Estudos Sociais - CCHLA/UFRN, em convênio com a Universidade de Coimbra (Portugal). Membro da Rede de Pesquisadores em Folkcomunicação - Rede FOLKCOM. E-mail: ricarteazevedo@gmail.com 